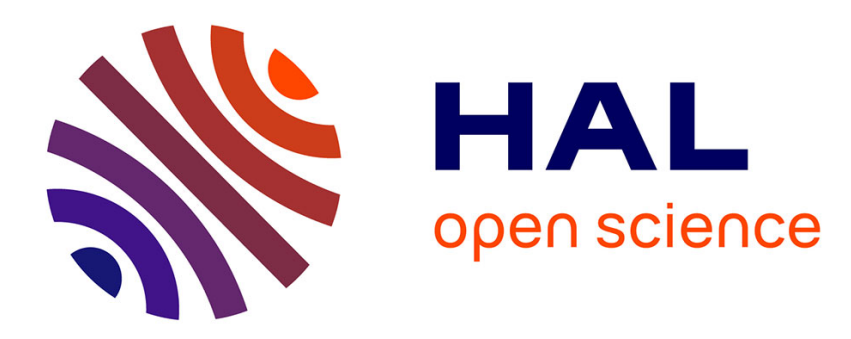

\title{
Monetary Policy Autonomy in European Non-Euro Countries, 1980-2005
}

Thomas Plümper, Vera E. Troeger

\section{To cite this version:}

Thomas Plümper, Vera E. Troeger. Monetary Policy Autonomy in European Non-Euro Countries, 1980-2005. European Union Politics, 2006, 7 (2), pp.213-234. 10.1177/1465116506063708 . hal00571725

\section{HAL Id: hal-00571725 \\ https://hal.science/hal-00571725}

Submitted on 1 Mar 2011

HAL is a multi-disciplinary open access archive for the deposit and dissemination of scientific research documents, whether they are published or not. The documents may come from teaching and research institutions in France or abroad, or from public or private research centers.
L'archive ouverte pluridisciplinaire HAL, est destinée au dépôt et à la diffusion de documents scientifiques de niveau recherche, publiés ou non, émanant des établissements d'enseignement et de recherche français ou étrangers, des laboratoires publics ou privés. 


\section{EUP}

European Union Politics

DOI: 10.1177/1465116506063708

Volume 7 (2): 213-234

Copyright@ 2006

SAGE Publications

London, Thousand Oaks CA, New Delhi

\section{KEY WORDS}

- currency union

- euro

- monetary policy

- monetary policy autonomy

- optimal currency area
Monetary Policy Autonomy in European Non-Euro

\section{Countries, 1980-2005}

\author{
Thomas Plümper
}

University of Essex, UK

Vera E. Troeger

University of Exeter, UK, and Max-Planck-Institute of Economics, Jena

\section{ABSTRACT}

We argue that the European currency union (ECU) reduced the de facto monetary policy autonomy of EU countries abstaining from introducing the euro. The large share of imports from euro zone countries renders a close alignment of monetary policy to the interest rate set by the European Central Bank (ECB) necessary if the monetary authorities of countries outside the ECU want to impede the import of inflation from the euro zone or a declining competitiveness of the domestic industry. In turn, the increasing role of the euro as an international reserve medium equal to the US dollar reduced the monetary policy autonomy of countries importing more goods and services from the euro zone than from the dollar zone. An empirical analysis of monetary policy in the United Kingdom, Denmark and Sweden lends support to our theoretical argument. Analysing the shortterm adjustments of central bank interest rates in these three EU countries, which did not introduce the euro, we show that these countries' monetary policies more closely follow the ECB's policy than they followed the Bundesbank's policy before 1994. In addition, we demonstrate the diminishing influence of the dollar on monetary policy in the UK, Denmark and Sweden since the countries of the Economic and Monetary Union harmonized monetary policies. 
Ironically, the two sides of one debate sometimes refer to identical arguments. During the negotiations for a common European currency, John Major - then a rising star within the British Conservative Party and soon to be successor of Margaret Thatcher - opposed the introduction of the euro, arguing that it would remove monetary and fiscal policy autonomy from the member governments, including of course that of the United Kingdom. In a reply to these reservations, the German Chancellor Helmut Kohl claimed that a stable euro would 'Thatcherize' the continent by imposing needed fiscal and monetary responsibility on countries such as France and Italy (New York Times, 30 April 1997). Obviously, Major and Kohl had little if any disagreement over the consequences of a common European currency in respect to monetary policy autonomy. However, they drew opposing conclusions from the very same point.

At the end of the day, both politicians got their way. While 12 EU countries, including Italy and France, introduced the euro, three countries, namely Denmark, Sweden and the United Kingdom, abstained from abandoning their national currencies. In all three defecting countries, the decision to reject the euro resulted from an inextricable melange of public reservations against the euro, a general Euroscepticism, national pride and a positive attitude towards policy autonomy.

Yet, although the desire to maintain political autonomy in monetary policy provided one of the main reasons not to join the European currency union (ECU), the introduction of the euro did not leave the monetary policy of the bystanders unaffected. We argue that the introduction of the euro de facto reduced monetary policy autonomy for non-euro EU countries - thus gradually reducing the potential gains from remaining outside the euro area. Since the maintenance of monetary policy autonomy is a major incentive not to join a currency union, the decline in de facto monetary policy autonomy should, ceteris paribus, reduce the disincentives to join the union. Hence, the politics of 'splendid isolation' in monetary affairs did not fully pay off for the EU countries keeping their own currency. If the defence of political room for manoeuvre provided a major reason for shying away from the European currency union, governments proved to be at best partially successful.

Our argument depends on the observation that, when a monetary authority lowers the central bank interest rate or increases money supply, the domestic currency almost certainly depreciates. In turn, the prices of imported goods rise, implying a net wage loss for all voters. As a consequence, governments in democratic countries have strong incentives to avoid real depreciations of their currency against the currencies in which imported goods are denominated. The de facto monetary policy autonomy of governments can be low even if they maintain full legal autonomy. 
The introduction of the euro altered the rules of the game on international asset markets. Specifically, the euro attracts a greater quantity of international assets than the ECU countries' currencies jointly attracted previously. The ECU countries' share in trans-border positions of internationally operating banks rose from less than $20 \%$ to more than $40 \%$. When a third country cuts its interest rate with the aim of stimulating the economy, capital owners holding the currency of the third party are nowadays more likely to redirect their assets to the euro than to the D-Mark or the French franc, as they did before the euro came into being. Consequently, the devaluation of the third country's exchange rate against the EU countries becomes stronger whereas its exchange rate devaluation against the dollar weakens - both compared with the situation before the foundation of the European currency union. This would not have any effect on monetary policy if the third party imported as many goods and services from the euro zone as it did from the dollar zone. Since the EU countries UK, Denmark and Sweden have more intense trade relations with the EU than with the USA and other dollar countries, devaluation vis-à-vis the euro stimulates inflation more than an equal devaluation against the dollar. To avoid importing inflation, stable exchange rates with the euro became more important. Monetary policy autonomy has declined.

We analyse data on monetary policy in three non-euro countries to test the empirical implications of our theoretical model. In particular, we study the central bank interest rates of three EU members that chose not to sign the Economic and Monetary Union (EMU) treaty (the UK, Denmark and Sweden). Our empirical analysis of monetary policies in non-euro countries before and after the introduction of the euro lends ample support to our model. We find that the European non-euro countries closely align their monetary policy to the European central bank's monetary policy. They followed the German Bundesbank's interest rate changes much less before the EMU was created. At the same time, the influence of US monetary policy on the monetary policy of the countries in our sample diminished. We thus observe a shift in the relative importance of key currencies away from the dollar towards the euro.

The remainder of this paper proceeds in the standard way. We start with a brief literature review, which aims at laying the foundations for combining the Mundell-Fleming model with McKinnon's contribution to the theory of optimal currency areas and the 'fear of floating' literature. After employing such a combined model to explain how and why currency unions influence the de facto monetary policy autonomy of countries that largely trade with union members, we then test our argument. We examine how changes in the monetary policy of the Bundesbank and the European Central Bank, 
respectively, affect monetary policy in Sweden, Denmark and the UK. The influence of the euro far exceeds the D-Mark's influence on monetary policy in the three countries in our sample. The final section concludes with some broad remarks on de facto monetary policy autonomy and partisan competition in the EU and some possible linkages between our work and Andrew Rose's findings on the effect of currency unions on trade.

\section{The international political economy of monetary policy autonomy}

The Mundell-Fleming model dominates the political science literature on monetary policy in open economies (Bernhard et al., 2002; Franzese, 2002). The model claims that governments cannot achieve the three political goals of monetary policy autonomy, stable exchange rates and free capital flows simultaneously. At best, they have to sacrifice one goal. We show in this brief literature review that the adoption of the Mundell-Fleming model has led to a dichotomous notion of monetary policy autonomy: authorities in countries with flexible exchange rates can autonomously decide monetary policy whereas governments in countries with fixed exchange rates are unable to do so (Mundell, 1963; Fleming, 1962). If a dichotomous view of monetary policy autonomy were appropriate, then countries joining a monetary union would completely abandon monetary policy autonomy and countries maintaining a flexible exchange rate against the key currencies would fully maintain monetary flexibility. In what follows we draw on arguments put forward by McKinnon (1963) as well as by Calvo and Reinhart (2002). Among others, these authors have forcefully argued that the dichotomous view of monetary policy autonomy is misleading. As McKinnon has repeatedly claimed since the early 1970s, the de facto monetary policy autonomy of open economies with flexible exchange rates also crucially hinges upon the size of the country. Hence, monetary authorities in small open economies have de facto limited monetary policy autonomy even under a flexible exchange rate regime. Only large countries issuing key currencies - currencies in which international trade is denominated and in which capital owners hold their assets - are able to maintain (almost) complete monetary policy autonomy under flexible exchange rates.

Before we elaborate our argument, however, let us briefly reconsider the Mundell-Fleming workhorse model of monetary policy in open economies. As Mundell and Fleming argued, independently of each other, the absence of capital controls and a fixed exchange rate system impose strict restrictions on monetary policy autonomy. Governments cannot achieve the three political goals of open capital markets, stable exchange rates and monetary 
independence simultaneously. When capital controls are not a viable policy instrument, the government must use monetary policy to stabilize the exchange rate in the event of asymmetric business cycles and country-specific economic shocks. However, in a fixed exchange rate system, governments can exploit monetary policy to stabilize demand and consumption only if the monetary authority of the key currency area eases monetary policy as well. With business cycles being asynchronous, the need to stabilize the exchange rate ties the government's hand. Fixed exchange rate commitments reduce monetary policy autonomy because, under a fixed exchange rate system, domestic inflation must be close to the inflation rate of the anchor currency. If domestic inflation exceeds the inflation rate of the anchor currency, then the real exchange rate appreciates, though of course the nominal exchange rate remains stable. The domestic economy's competitiveness gradually weakens until the peg has to be abandoned or harsh stabilization policies must be implemented. At the same time, abandoning an exchange rate fix is economically and politically costly. On the economic side, giving up a peg may boost the costs of international lending. On the political side, an immediate depreciation of the domestic currency sharply reduces the purchasing power of voters.

Facing a trade-off between monetary policy credibility and monetary policy autonomy (Giavazzi and Pagano, 1988; Lohmann, 1992), many countries chose the former. Especially in Europe, many central banks in effect designated the Deutsche Bundesbank as their conservative central banker. Over almost two decades, the exchange rate of the Austrian schilling and the Dutch guilder against the D-Mark moved within very narrow bands. Governments seeking to enhance credibility always peg their currency to large lowinflation countries; thus, currency pegs significantly lower inflation (Keefer and Stasavage, 2002).

The rationale for pegging, however, does not solely result from the incentive to increase credibility; stable exchange rates also moderate the transaction costs of international trade and may therefore foster economic growth (Rose, 2000)..$^{1}$ Currency unions have at least the same effect as an exchange rate peg (Alesina and Barro, 2002), but differ in two respects from fixed exchange rates. First, whereas in the case of a fixed exchange rate system the key currency's monetary authority preserves full policy autonomy, all countries joining a union surrender monetary policy autonomy to a joint central bank - which is the main difference from dollarization. Secondly, leaving a currency union is more costly than abandoning a fixed exchange rate regime. Being a member of a currency union should lend more credibility to monetary policy than an exchange rate peg does.

The dichotomous view of exchange rate pegs - countries credibly pegging their currency and thus forsaking monetary policy autonomy versus countries choosing a flexible exchange rate regime and maintaining full 
autonomy - was adopted by numerous political scientists. For instance, Bernhard, Broz and Clark, in their insightful introduction to International Organization's special issue on monetary institutions, contend: 'When a nation fixes its currency's value to that of another nation, it is, to a large extent, delegating monetary policy to a foreign central bank. The pegging nation not only forgoes exchange-rate flexibility as a policy tool, it also subordinates its monetary policy to that of a foreign central bank' (Bernhard et al., 2002: 695). Arguing likewise, Broz and Frieden (2001: 322) add that 'pegging . . . has costs. To gain the benefits of greater economic integration by fixing the exchange rate, governments must sacrifice their capacity to run an independent monetary policy. ${ }^{2}$

The Mundell-Fleming model also gave rise to an extensive literature on 'optimum currency areas' (Mundell, 1961; McKinnon, 1963; Kenen, 1969; Frankel and Rose, 1997; Bayoumi and Eichengreen, 1996) and ultimately led to the burgeoning literature on currency unions (Alesina and Barro, 2002). According to Mundell, as well as to Alesina and Barro, a currency area is desirable if (a) the regions in the area trade extensively, and (b) the regions have sufficiently symmetrical business cycles. Then gains from the removal of currency barriers to trade are large while the costs of having a common monetary policy are relatively low. Hence, currency unions have two opposing consequences: on the one hand, member states benefit since a joint currency lowers trading costs and thereby generates efficiency gains; on the other hand, a single currency precludes the implementation of independent monetary policies. When a country has joined a currency union, monetary policies can no longer be tailored to country-specific economic shocks (Mundell, 1961, 1963).

This line of reasoning is definitely not wrong but it remains incomplete. In the early 1970s Ronald McKinnon claimed that, even in flexible exchange rate systems, governments enjoy only limited de facto monetary policy autonomy under certain conditions. For instance, governments in small open economies fail to stimulate the economy by lowering the central bank interest rates because they will experience a devaluation of the domestic currency against the key currency, which in turn raises the price of imported goods. As a consequence, countercyclical monetary policy always leads to more inflation, and this effect is stronger the smaller the economy is. Small open economies possess rather limited de facto monetary policy autonomy even if they have implemented a flexible exchange rate regime.

As McKinnon (2004) states, currency unions, in addition to affecting government policies, also influence the economic decisions of private corporations and capital owners. With a currency union expanding the size of a key currency area, the use of the union's currency in international bonds and asset 
markets increases more than proportionally. In other words, economic agents tend to favour larger currencies over smaller currencies, ceteris paribus. As a consequence, the euro plays a more important role in international financial markets than the aggregate of the ECU countries' independent currencies did. The euro has caught up with the dollar in attracting the denomination of bonds and assets, and these structural changes in the international financial markets have important macroeconomic implications, which also affect the monetary policies of countries outside the union.

Another challenge to the unholy trinity theory stems from the 'fear of floating' (Calvo and Reinhart, 2002) literature. In a nutshell, the 'fear of floating' approach holds that, for various reasons, countries with flexible exchange rates choose not to use monetary policy to stabilize the domestic economy. Among these reasons, credibility, exchange rate pass-through and foreign currency liability rank most prominently. The 'fear of floating' prevents countries with de jure flexible exchange rate regimes from allowing their exchange rates to move freely. Many countries that are formally floating in fact follow the monetary policy of key-currency countries as much as countries with fixed exchange rate arrangements do. Capital markets are so tightly integrated that non-pegged countries also lack monetary freedom. Any interest rate policy other than following the base interest rate generates immediate exchange rate fluctuations beyond the amount most countries are willing to tolerate.

For these various reasons, the Mundell-Fleming model falls short as an explanation of the impact of the international economy on domestic monetary policy. Even though monetary authorities lose monetary policy autonomy if they peg their exchange rate (given the absence of capital controls), they do not enjoy perfect de facto autonomy under their flexible exchange rate system. Under a floating regime it might still be rational for the government to defend relatively stable exchange rates. In practice, formally autonomous monetary authorities often enjoy rather limited real autonomy. ${ }^{3}$

In the next section, we provide reasons for the existence of external effects of currency unions. We demonstrate that small open countries are less likely to draw on their legal monetary policy autonomy. We then show why currency unions reduce the de facto monetary policy autonomy of countries outside the union.

\section{Theory}

Our theoretical argument builds on the seminal work of Mundell and Fleming on monetary policy in open economies as well as on McKinnon's work on 
optimal currency areas and on the relation between country size and monetary policy autonomy (Mundell, 1963; Fleming, 1962). Decades later, these arguments have been formalized by political economists who assert that governments aim at minimizing a loss function in which inflation and deviations from optimal consumption both enter quadratically (Barro and Gordon, 1983; Rogoff, 1985). Consequently, a government maximizes its political support when it combines high consumption with low levels of inflation.

This argument easily applies to open economy macroeconomics. In an open economy, inflation results from domestic monetary policy and from the exchange rate effects of monetary policy (Meese and Rogoff, 1983). Assume a small open country experiencing an economic shock, which motivates the government to stabilize consumption by adjusting the key interest rate downwards. If other countries do not encounter the same economic shock and therefore do not cut interest rates, capital owners in the first country start transferring capital into other currencies. Hence, the domestic currency depreciates and - in turn - the prices of imported goods in the domestic currency rise. The effect of countercyclical monetary policy on the inflation rate thus depends on changes in the real interest rate difference and the degree of economic openness of the country using monetary policy to offset the economic shock. The larger the drop in the real interest rate and the larger the economic openness of the country, the more the inflation rate accelerates, ceteris paribus.

True, this ceteris paribus condition does not always hold. Under certain conditions, foreign corporations prefer to reduce profits rather than to observe a decline in sales and market share. By accepting lower profit rates they stabilize the market price of the goods they sell despite the appreciation of the currency in which they produce against the currency in which they sell their products. However, this offsetting effect remains limited. Take, for instance, the oil industry, which has no incentive to lower prices to stimulate demand in a country whose currency has depreciated. More generally, Shambaugh (2005) has demonstrated that the import price pass-through is almost perfect, lending support to the idea that import prices tend to be set in the producer's currency. This implies that currency devaluation leads to an increase in the prices of imported goods.

The relation between exchange rates, economic openness and monetary policy has strong political implications. Most importantly, governments in small open economies are less likely to exploit monetary policy for stabilizing demand and consumption. Thus, governments in small open economies are more likely to choose an exchange rate peg or to join a currency union (Alesina and Barro, 2002). Since these countries experience limited monetary policy autonomy, governments are also more likely to surrender monetary policy to an independent central bank. 
Departing from a McKinnon-type theory, it is not difficult to see how a currency union affects the monetary policy of outside countries. Yet a second look reveals that the argument is not trivial either. Let us briefly discuss what our argument is not. We do not derive the reduction in monetary policy autonomy from the fact that the establishment of a currency union reduces the relative size of outside countries. Since a currency union is not larger than the sum of its parts, we believe that seemingly straightforward size arguments are wrong. Hence, we do not claim here that a simple relative size effect reduces the policy autonomy of outside countries.

Our argument is less simplistic and depends on the impact of the size of a currency union on the behaviour of investors - that is, on the size bias rather than simply on size. 'Size bias' refers to the preference of investors to hold their assets in a large rather than a smaller currency. Hence, size bias implies that investors hold more euro-denominated assets than they held assets denominated in the currencies that are now part of the euro. The larger the area of a currency, the more likely are capital owners to perceive the currency as a 'safe haven'. In other words, the extent to which capital owners use a currency as a 'safe haven' depends on the relative size of currency areas, with larger currency areas being more attractive. The euro is, thus, in at least one respect more than the sum of its parts (two examples that illustrate this argument are provided in Appendix A, which can be found on the EUP webpage).

This being correct, a larger share of internationally traded bonds and banks' cross-border assets should be denominated in euros. And, indeed, we can observe exactly that:

Within Euroland, private euro-denominated bond issues grew explosively after January 1, 1999. Overall euro bond issues in the first half of 1999 were 80 percent higher than a tabulation of all bond issues in the old legacy currencies for the first six months of 1998. Most strikingly, issues of euro-denominated corporate bonds were almost four times as high in 1999 as compared to 1998. (McKinnon, 2004: 701)

McKinnon's observation finds additional supportive evidence in current financial markets. Since the introduction of the euro, the dollar has lost its dominance in international capital markets. Nowadays, international assets are denominated almost as much in euros as in dollars (see Figure 1). Most importantly, the euro did not just attract the assets previously denominated in the existing European currencies. Rather, the share of the euro in international asset markets exceeds the share of the D-Mark and the franc by about a factor of 2 .

In the early 1990s, the dollar accounted for more than $60 \%$ of total assets, whereas the total share of all ECU countries stagnated at about $12 \%$. At the 


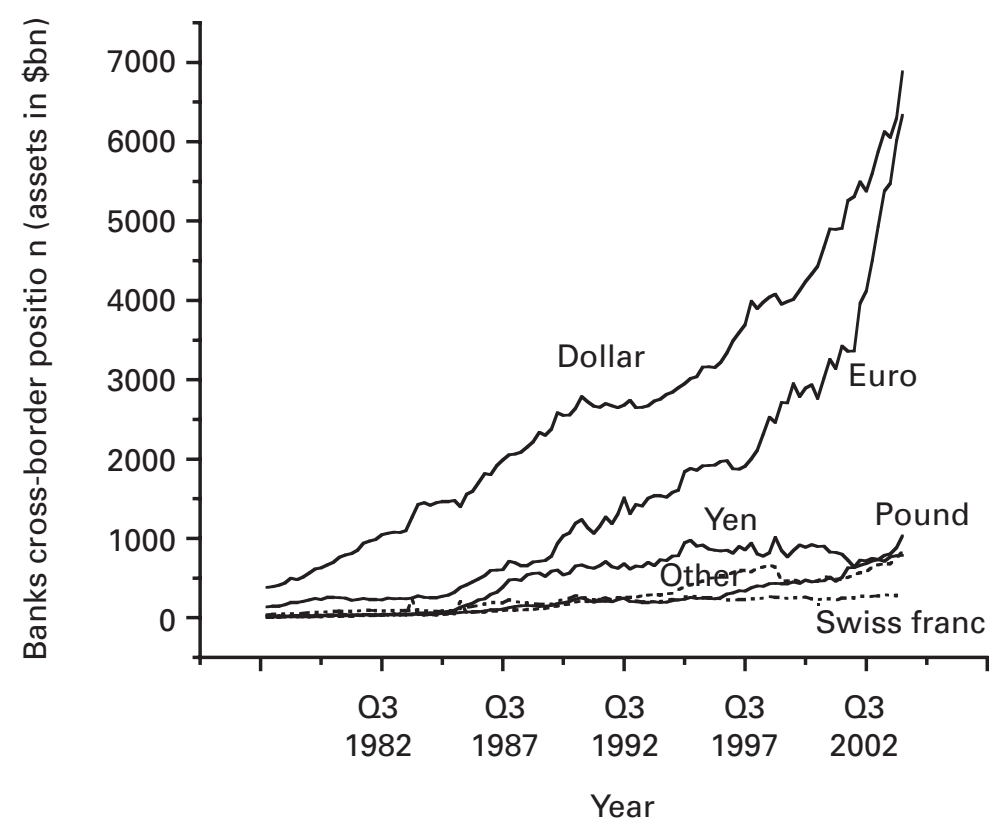

Figure 1 Currency denomination of BIS reporting banks' cross-border positions (assets), 1977-2004.

Source: Bank for International Settlements (2004).

end of 2003, about $40 \%$ of banks' international cross-border positions were denominated in dollars and euros. Thus, the euro has not simply attracted assets previously being held in the ECU countries' currencies. Rather, it has attracted assets that, without the introduction of the euro, would have been denominated in dollars (Galati and Tsatsaronis, 2001).

How do these developments in the international financial markets affect exchange rates and ultimately monetary policy in non-euro countries? When interest rates plunge, capital owners search for more attractive assets. A drop in the interest rates thus may imply a shift from the bond market and from short-term assets to the stock exchange. However, a cut in one country's shortterm interest rates also propels some assets into short-term assets denominated in other currencies and especially in key currencies known to be 'safe havens'.

Before the advent of the euro, the dollar was the most attractive 'safe haven' when a country significantly reduced its domestic interest rate. In this case, the domestic currency depreciated more against the dollar than it depreciated against the D-Mark, the French franc and other reserve currencies. In turn, not only did the dollar appreciate against the currency of the country that had adjusted its interest rate to lower demand; but the US currency to a lesser extent also appreciated against all other currencies. 
If we assume that capital owners behave identically, then the changes in the global financial markets affect the monetary policy of all but those countries that import about equally from dollar countries and euro zone countries. Countries that import more from dollar countries actually gain in monetary policy autonomy, whereas countries that import relatively more from the euro zone lose monetary policy autonomy. In other words, if a country reduces its interest rate relative to those of the key currency areas, its currency nowadays depreciates relatively more against the euro and relatively less against the dollar than before the introduction of the common European currency. The more open the country is and the more it imports from the euro zone, the more this shift in exchange rate adjustments increases the size of the imported inflation. Accordingly, countries that predominantly import goods and services from the dollar zone gain in monetary policy autonomy, and euro zone dependent countries lose in monetary policy autonomy.

To sum this argument up, countries' monetary policy autonomy declines if

(a) the currency union issues a key currency,

(b) the new key currency is more widely used than the previous key currency (i.e. the euro appears more important for international monetary transactions than the D-Mark was), and

(c) the neighbouring countries import more goods and services from the currency union than from competing key currency areas.

If conditions (a) and (b) do not hold, then the establishment of the currency union has no impact on the monetary policy of outside countries. On the other hand, neighbouring countries gain monetary policy autonomy if condition (c) does not hold. In other words, conditions (a) to (c) are necessary for a reduction in outside countries' monetary policy autonomy when a currency union establishes a new, or expands the size of an old key currency area.

For the countries in our sample, the predictions are straightforward: since these countries import much more goods and services from euro zone countries, they lose in monetary policy autonomy. The following section puts this argument to the test.

\section{Analysis: The effect of currency unions on the monetary policy of outsiders}

The theoretical argument presented in the previous section implies that the establishment of a currency union has external effects if the currency union affects the size of a key currency area. ${ }^{4}$ Since the expanded key currency is a 
more attractive 'safe haven' for internationally mobile capital, the monetary authorities of countries outside the union place greater weight on defending their exchange rate against the increasingly important union's currency.

We test the hypotheses derived from the theoretical discussion of the previous section by analysing the influence of the EMU/euro on EU members abstaining from the European Monetary Union (the UK, Sweden and Denmark). As dependent variables we choose the change in the 'actual instrument used by most central banks to impose their policy - the short-term interest rate' (Obstfeld et al., 2004: 3). We follow the current empirical procedure employed by many economists (see Frankel et al., 2002; Obstfeld et al., 2004; and Shambaugh, 2004). However, we do not follow these economists in their choice of model specifications. For instance, Obstfeld et al. (2004) and Shambaugh (2004) run a simple pooled ordinary least squares estimator in differences; Frankel et al. (2002) run separate autoregressive distributed lag models for each country. As Obstfeld et al. and Shambaugh have emphasized, a differenced estimator removes serial correlation and unit roots, but even after eliminating serial correlation we observe time-dependent error variances. In particular, the variance of the dependent interest rates reveals time dependency, which violates one of the Gauss-Markov assumptions of linear regression models. Not controlling for variance heterogeneity would render estimates inefficient and thus unreliable (Plümper and Troeger, 2005b), although they are still consistent (Wooldridge, 2003: 416). We run PanelGARCH (generalized autoregressive conditional heteroscedasticity) models. This estimator not only estimates the usual mean equation of linear models but also specifies a variance equation. While the conditional mean function estimates the expected values of the endogenous variable with respect to our theoretically inspired exogenous variables (the German and US interest rates, domestic inflation, growth, etc.), the variance equation controls for the time dependency of the endogenous variable's variance by regressing the variance of the endogenous variable on the lagged values of the squared residuals (ARCH term) plus the lagged values of the forecasted variance (GARCH term). Thus, ARCH models rely on the assumption that present realizations of time series depend on past information, accounting for the observation that time series volatility comes in clusters and that periods of high volatility are followed by periods of low volatility. This holds true for the mean as well as the variance of the dependent variable. One might argue that the volatility of interest rates is associated with exogenous shocks or can be explained substantially and not only by time dependence. However, we are mostly interested in the direct mean effects of the monetary policy set in the euro zone and therefore treat the time dependency of the variance as a mere nuisance that must be controlled for in order to render the estimates more efficient. 
Both differencing the dependent variable and estimating a GARCH model remove variations over time in the level of the real interest rate. Thus, our results cannot be driven by long-term variations in the level of the central bank's main interest rate or by a convergence of inflation rates.

We are mostly interested in examining the determinants of the discount rate (the rate at which the central banks lend eligible paper to deposit money banks). Yet our results remain substantively robust if we replace the discount rate by other financial market indicators of central bank policy, especially the deposit rate (see Appendix B on the EUP webpage). With daily data being unavailable for our control variables, we study monthly data. Our sample spans the period from 1980 to 2005, where changes in the first considered data-point do not alter the results. By concentrating exclusively on changes in the real interest rates, we reduce the available cross-sectional variance, but at the same time remove the differences in levels resulting from different types of central bank interest rates and eliminate non-stationarity in the data. Unit roots render the estimated coefficients of time series models in levels inefficient. Here, differencing the data is required, since our data set includes far more time-points than cross-sectional observations (countries). Wu and Zhang (1997) show that levels of interest rates are trended and at least close to non-stationarity, and Granger and Newbold (1974) argue that the estimated relationship between two independent integrated time series often leads to spurious regression results. Co-integration tests show that the dependent and independent interest rate series are not co-integrated and do not constitute a long-term equilibrium. This finding prevents co-integration analysis and leaves us with differencing the time series to generate sound estimation results. In addition, and more importantly, differencing appears to be theoretically plausible because we are interested in short-term adjustments rather than long-term effects. This means we look at the immediate reactions of the monetary authorities in the outsider countries to the monetary policy changes of the European Central Bank. Consequently, we employ real interest rates (the central bank interest rate minus the inflation rate) to eliminate noisy short-term variations in the interest rates.

We regress real interest rate changes in the UK, Sweden and Denmark on import-weighted real interest rate changes of the key currency (DMark/euro). ${ }^{5}$ We took monthly trade data from the International Monetary Fund's Direction of Trade Statistics to compute relative import shares from the euro zone and from the USA. According to our theoretical argument, the higher countries' imports from the euro zone, the more closely they follow the ECB's monetary policy. We thus weight the ECB's and US interest rate policy by import shares from key currency areas to test this argument. Our results stay largely robust if we - contrary to our theory - do not weight the 
monetary policy of central banks issuing key currencies. However, the level of significance decreases. ${ }^{6}$

More importantly, our theory finds support if the outsiders' monetary policy follows the real interest rates of the euro zone more closely than it followed Germany's interest rate before the establishment of the euro. We therefore estimate the slopes of our main variable for five time periods. The cut-off points within the time series have been specified for two purposes. The first is substantive: in July 1990, the EMU countries fully liberalized capital accounts vis-à-vis each other and enforced monetary policy coordination. In January 1994, the central banks of the EMU began to coordinate and harmonize interest rate policies more closely. At the same time, the European System of Central Banks became effective. In January 1999, the EMU countries fixed their exchange rates and introduced the euro. Finally, in January 2002 the euro became the sole means of payment in all EMU countries. The second reason is theoretical: according to expected utility models, capital owners and central banks may have anticipated the existence of a single European currency (Persson and Tabellini, 1990). We account for these expectations by allowing adjustment before 1999.7 We expect, however, a stronger effect after 1999. 8

In model 3 we control for the growth of GDP and the level of the real interest rate in the countries under observation, as well as for the German growth rate and changes in the exchange rate. The inclusion of additional variables aims at controlling for business cycle influence on monetary policy. The controls are likely to influence the central bank interest rate, but are unlikely to be correlated with the variables of main interest. As a consequence, the exclusion of all controls would not significantly change our results.

Finally, we also control for the monetary policy of the Federal Reserve System. Again, the inclusion of this variable has two motivations. On the one hand, including US monetary policy provides an additional robustness check. On the other hand, however, our model predicts that the influence of the dollar interest rate on the monetary policy of the three EU members in our sample declines.

To investigate the robustness of our findings further, we report results from a model that controls for unit fixed effects. As some authors claim, fixed effects models control for country-specific time-invariant variables (such as institutions) not explicitly modelled. Neither the inclusion of control variables nor the inclusion of $N-1$ country dummies has substantial effects on the estimated coefficients of our theoretically interesting variables. Table 1 lists all regression results for the German/euro interest rate in the $\operatorname{GARCH}(1,1)^{9}$ specification.

Before we discuss the substantive results, let us briefly point out that 
Table 1 Determinants of monetary policy in Denmark, Sweden and the UK, 1980-2002

\begin{tabular}{|c|c|c|c|}
\hline $\begin{array}{l}\text { Dependent variable: changes in real } \\
\text { interest rates of non-EMU countries } \\
\text { (Den, Swe, UK) }\end{array}$ & $\begin{array}{l}\text { Model } 1 \\
\text { Unweighted }\end{array}$ & $\begin{array}{l}\text { Model } 2 \\
\text { Trade } \\
\text { weighted }\end{array}$ & $\begin{array}{l}\text { Model } 3 \\
\text { Trade } \\
\text { weighted }\end{array}$ \\
\hline \multicolumn{4}{|l|}{ Mean equation: } \\
\hline Intercept & $\begin{array}{l}-0.046^{* *} \\
(0.020)\end{array}$ & $\begin{array}{l}-0.044^{* *} \\
(0.020)\end{array}$ & $\begin{array}{l}-0.561 * * * \\
(0.108)\end{array}$ \\
\hline $\begin{array}{l}\text { Level of real interest rate } \\
\text { (DNK, SWE, UK) }\end{array}$ & $\begin{array}{l}0.021 * * * \\
(0.006)\end{array}$ & $\begin{array}{l}0.020^{* * *} \\
(0.006)\end{array}$ & $\begin{array}{l}0.047 * * * \\
(0.008)\end{array}$ \\
\hline$\Delta$ Real interest rate Germany, $1980-90$ & $\begin{array}{c}0.015 \\
(0.064)\end{array}$ & $\begin{array}{c}0.041 \\
(0.067)\end{array}$ & $\begin{array}{c}0.029 \\
(0.076)\end{array}$ \\
\hline$\Delta$ Real interest rate Germany/euro & & & \\
\hline zone, 1990-94 & $\begin{array}{c}0.059 \\
(0.067)\end{array}$ & $\begin{array}{c}0.053 \\
(0.068)\end{array}$ & $\begin{array}{c}0.032 \\
(0.073)\end{array}$ \\
\hline$\Delta$ Real interest rate euro zone, $1994-99$ & $\begin{array}{l}0.238^{* *} \\
(0.118)\end{array}$ & $\begin{array}{l}0.241^{* *} \\
(0.118)\end{array}$ & $\begin{array}{l}0.266^{* * *} \\
(0.102)\end{array}$ \\
\hline$\Delta$ Real interest rate euro zone, $1999-2002$ & $\begin{array}{l}0.353^{* * *} \\
(0.104)\end{array}$ & $\begin{array}{l}0.352^{* * *} \\
(0.102)\end{array}$ & $\begin{array}{l}0.339 * * * \\
(0.107)\end{array}$ \\
\hline$\Delta$ Real interest rate euro zone, $2002-05$ & $\begin{array}{l}0.493^{* * *} \\
(0.073)\end{array}$ & $\begin{array}{l}0.611^{* * *} \\
(0.127)\end{array}$ & $\begin{array}{l}0.601 * * * \\
(0.133)\end{array}$ \\
\hline$\Delta$ Real interest rate USA, $1980-90$ & $\begin{array}{c}-0.011 \\
(0.035)\end{array}$ & $\begin{array}{c}-0.016 \\
(0.031)\end{array}$ & $\begin{array}{c}-0.034 \\
(0.033)\end{array}$ \\
\hline$\Delta$ Real interest rate USA, 1990-94 & $\begin{array}{l}0.150 * * * \\
(0.054)\end{array}$ & $\begin{array}{l}0.143^{* * *} \\
(0.046)\end{array}$ & $\begin{array}{l}0.160 * * * \\
(0.046)\end{array}$ \\
\hline$\Delta$ Real interest rate USA, 1994-99 & $\begin{array}{c}0.078 \\
(0.084)\end{array}$ & $\begin{array}{l}0.074 \\
(0.075)\end{array}$ & $\begin{array}{c}0.072 \\
(0.059)\end{array}$ \\
\hline$\Delta$ Real interest rate USA, 1999-2002 & $\begin{array}{c}0.024 \\
(0.021)\end{array}$ & $\begin{array}{c}0.018 \\
(0.020)\end{array}$ & $\begin{array}{c}0.025 \\
(0.021)\end{array}$ \\
\hline$\Delta$ Real interest rate USA, 2002-05 & $\begin{array}{c}0.026 \\
(0.017)\end{array}$ & $\begin{array}{c}0.013 \\
(0.020)\end{array}$ & $\begin{array}{c}0.011 \\
(0.031)\end{array}$ \\
\hline Exchange rate against DM/Euro & & & $\begin{array}{l}0.040 * * * \\
(0.010)\end{array}$ \\
\hline Exchange rate against US\$ & & & $\begin{array}{c}0.006 \\
(0.012)\end{array}$ \\
\hline Growth (Den, Swe, UK) & & & $\begin{array}{c}0.007 \\
(0.007)\end{array}$ \\
\hline Growth Germany/euro zone & & & $\begin{array}{l}-0.005 \\
(0.005)\end{array}$ \\
\hline Growth USA & & & $\begin{array}{l}0.035^{* * *} \\
(0.006)\end{array}$ \\
\hline
\end{tabular}


Table 1 Continued

\begin{tabular}{|c|c|c|c|}
\hline $\begin{array}{l}\text { Dependent variable: changes in real } \\
\text { interest rates of non-EMU countries } \\
\text { (Den, Swe, UK) }\end{array}$ & $\begin{array}{l}\text { Model } 1 \\
\text { Unweighted }\end{array}$ & $\begin{array}{l}\text { Model } 2 \\
\text { Trade } \\
\text { weighted }\end{array}$ & $\begin{array}{l}\text { Model } 3 \\
\text { Trade } \\
\text { weighted }\end{array}$ \\
\hline FE Sweden & & & $\begin{array}{c}-0.060^{*} \\
(0.034)\end{array}$ \\
\hline FE UK & & & $\begin{array}{l}0.178 * * \\
(0.088)\end{array}$ \\
\hline \multicolumn{4}{|l|}{$\chi^{2}$-test difference of EMU coef } \\
\hline $80-90=99-02\left(p>\chi^{2}\right)$ & $\begin{array}{l}7.72 * * * \\
(0.006)\end{array}$ & $\begin{array}{l}6.67 * * * \\
(0.010)\end{array}$ & $\begin{array}{c}5.74 * * \\
(0.017)\end{array}$ \\
\hline \multicolumn{4}{|l|}{$\chi^{2}$-test difference of EMU coef } \\
\hline $90-94=99-02\left(p>\chi^{2}\right)$ & $\begin{array}{c}5.79 * * \\
(0.016)\end{array}$ & $\begin{array}{c}6.16^{* *} \\
(0.013)\end{array}$ & $\begin{array}{c}5.59 * * \\
(0.018)\end{array}$ \\
\hline \multicolumn{4}{|l|}{$\chi^{2}$-test difference of EMU coef } \\
\hline $90-94=02-05\left(p>\chi^{2}\right)$ & $\begin{array}{l}19.23^{* * *} \\
(0.000)\end{array}$ & $\begin{array}{l}14.92^{* * *} \\
(0.000)\end{array}$ & $\begin{array}{l}13.84^{* * *} \\
(0.000)\end{array}$ \\
\hline \multicolumn{4}{|l|}{ Variance equation: } \\
\hline Intercept & $\begin{array}{c}0.0004 \\
(0.0005)\end{array}$ & $\begin{array}{c}0.0003 \\
(0.0005)\end{array}$ & $\begin{array}{c}0.001 \\
(0.001)\end{array}$ \\
\hline ARCH $1\left(\epsilon_{t-1}^{2}\right)$ & $\begin{array}{l}0.061 * * * \\
(0.006)\end{array}$ & $\begin{array}{l}0.062^{* * *} \\
(0.006)\end{array}$ & $\begin{array}{l}0.097^{* * *} \\
(0.013)\end{array}$ \\
\hline GARCH $1\left(\sigma_{t-1}^{2}\right)$ & $\begin{array}{l}0.936 * * * \\
(0.005)\end{array}$ & $\begin{array}{l}0.936^{* * *} \\
(0.005)\end{array}$ & $\begin{array}{l}0.902 * * * \\
(0.011)\end{array}$ \\
\hline$N$ & 906 & 900 & 900 \\
\hline $\begin{array}{l}\text { Wald } \chi^{2} \\
\qquad\left(\text { Prob }>\chi^{2}\right)\end{array}$ & $\begin{array}{l}94.92 \\
(0.000)\end{array}$ & $\begin{array}{l}75.71 \\
(0.000)\end{array}$ & $\begin{array}{l}172.60 \\
(0.000)\end{array}$ \\
\hline Log likelihood & -704.615 & -700.825 & -688.963 \\
\hline
\end{tabular}

Note: Standard errors in parentheses.

${ }^{* * *} p<.01 ;{ }^{* *} p<.05 ;{ }^{*} p<.1$

estimation of the variance equation reveals the necessity of controlling for autoregressive conditional heteroscedasticity. Both the $\mathrm{ARCH} 1$ and the GARCH 1 terms remain positive and significant in all the models we ran. Obviously, interest rates are not only highly volatile over time, but the variance at time $t$ also depends on the variance at $t-1$. Ignoring this fact would have rendered estimates inefficient and most likely unreliable. With the sum of the ARCH and the GARCH terms falling short of unity, our estimates conform to the stability condition for ARCH models. ${ }^{10}$ Finally, having taken first differences and controlled for $\mathrm{ARCH}$, the residuals are white noise. 
Coming to the substantive results, we find ample support for our theoretical model. Changes in the key currency's interest rate have the assumed significant and positive effect on the decision of EMU outsiders to adjust their interest rates. This holds true for the whole period under observation. Observe model 1 first. The estimated coefficient for changes in the D-Mark interest rate on changes in the sample countries' monetary policy is .015 between 1980 and 1990. Accordingly, for any percentage point change in the German interest rate, the three central banks adjusted their interest rates by only 0.02 percentage points. In other words, their monetary policy was independent of the German monetary policy. We do not observe a significant effect of the German interest rate before 1994. Between 1994 and 1999, Denmark, Sweden and the UK adjusted their interest rates by about 0.24 percentage points for any percentage change in the D-Mark interest rate. Between 1999 and 2002, the euro's influence rose to 0.35 percentage points and after 2002 to 0.49 percentage points.

Weighting the monetary policy in the key currency area by the imports from the key currency area (models 2 and 3), the impact of the introduction of the euro on the monetary policy of European non-members becomes stronger. Using trade as weights, Denmark, Sweden and the UK changed their interest rate by more than 0.6 percentage points for any percentage point change of the euro interest rate after 2002. In other words, these three countries currently resemble ' $60 \%$ members' of the euro zone. Again, we observe a drastic and significant increase in the dependence of Danish, Swedish and UK monetary policy on the monetary policy of Europe's key currency (see the $\mathrm{t}^{2}$ tests in Table 1).

As model 3 reveals, these results remain robust to the inclusion of additional controls, to estimating a fixed-effects GARCH model, and to another operationalization of the dependent variable, such as deposit rates (see Appendix B on the EUP webpage) and short-term rates. Finally, the size and significance of the coefficients for the variables of main interest are stable with regard to a wide variety of model specifications, the inclusion of additional controls and different timing. We also estimated single time series models for each of the three countries. The results appear to be consistent with the pooled regression estimates.

Thus, we found no evidence that could falsify our hypothesis. The influence of the key currency on the monetary policy of EMU outsiders is positively related to the size of the key currency area. As predicted, monetary policy autonomy - the main reason for abstaining from the union - decreases even in countries abstaining from joining the union. Both the growth rate of the countries in our sample and the German growth rate are positively related to the real interest rate differentials. Although central banks apparently 
observe the macroeconomic situation in the key currency area, the estimated effect is small and only the growth in the key currency area reaches standard levels of significance.

Our theory gains further support from the estimated influence of the dollar interest rate on the monetary policy of the three countries in our sample. Whereas the influence of monetary policy in the euro zone on the central bank interest rates of the UK, Denmark and Sweden rose after 1994, the influence of the US interest rate changes was negligible after that date. Monetary policy in fact followed the relative attractiveness of international key currencies.

To sum up, the empirical tests of our theoretical model lend support to our theoretical claims. The de facto monetary autonomy of countries outside the European monetary union decreased as a consequence of the harmonization of central bank policies in the EMU and, more importantly, as a consequence of the introduction of the euro.

\section{Conclusion}

The euro has changed the rules of the game in international financial markets and, accordingly, reduced monetary policy autonomy in small countries with flexible exchange rate regimes. This paper advances our understanding of the role of currency unions in monetary policy autonomy in neighbouring countries. In particular, it demonstrates that the exchange rate goal becomes more important for a country issuing its own currency when the size of the key currency area increases.

Of course, significant changes in the relative size of key currency areas tend to be rare and moderate. But there is one exception to this rule: the formation of a currency union. If a nucleus of countries establishes a new currency union, outsiders experience a surge in the need to stabilize exchange rates. De facto monetary policy autonomy therefore declines with the introduction of a currency union incorporating the former (regional) key currency. Nowadays, the prime interest rates of non-euro countries closely follow the monetary policy agreed upon by the European Central Bank.

Our theoretical argument opens interesting avenues for future research. For example, Andrew Rose has argued that a currency union fosters trade between members of the union and may even raise trade diversion; that is, trade within the union increases at the expense of trade between union members and non-union members. In the latter case, two consequences for the countries outside the union are possible: either their trade openness declines gradually, or they substitute trade with the union members by trade 
with non-union members. Whichever scenario dominates, the indirect consequences of a trading union should moderate the influence of currency unions on the monetary policy autonomy of outside countries that we describe here.

In addition, our research speaks to the increasing number of scholars who are interested in the effect of European integration on partisan platform convergence in the EU member countries. We have shown that not only do policy autonomy and the room for political competition suffer as a consequence of the harmonization of policies across the EU countries, but intensified economic policy spillovers also impose a certain, sometimes restrictive, ceiling on monetary policy autonomy and effective partisan competition.

\section{Notes}

1 Eichengreen and Leblang (2003) observed no significant and robust relationship between pegged currencies and economic growth. However, when considering different historical types of peg, they identified an insignificant positive effect after the collapse of the Bretton Woods system. Bernhard and Leblang (1999) found that countries are more likely to peg their currencies if they have a relatively low growth rate before.

2 The question of whether these costs exist dominates the current debate in the UK. Critics warn that it is counterproductive if countries with different economic structures and de-synchronized business cycles issue a single currency. Moreover, they claim that the Stability and Growth Pact limits the stabilizing capacity of monetary policy (Eichengreen and Leblang, 2003: 797).

3 The idea of non-legal limits to monetary autonomy is not completely new in the literature. For instance, Kaminsky and Reinhart claim that, once a monetary authority has lost its credibility in fighting inflation, it will probably face serious difficulties in counterbalancing economic shocks (Kaminsky and Reinhart, 1999; Hausmann et al., 2001). Kaminsky and Reinhart remain relatively subtle in their argument on monetary policy autonomy, but, as Jay Shambaugh (2004) states, all countries lack monetary policy autonomy, not just pegged countries and members of a currency union. Shambaugh empirically demonstrates that de facto monetary policy autonomy is most restricted in small countries (Shambaugh, 2004: 304).

4 A formalized version of this argument can be found in Plümper and Troeger (2005a).

5 Critics of previous versions of this paper argued that central banks control the nominal rather than the real interest rates. Their argument resembles a common assumption that unions can bargain not for real wage increases but only for nominal wage increases. Though this argument makes intuitive sense for unions, it is far less appealing for central banks for two reasons. The first reason is theoretical: central banks can if necessary adjust the interest rate on a daily basis, thus carefully adjusting monetary instruments to changes in the inflation rate. In other words, the central bank does not need to formulate nominal interest rate targets but can adjust monetary 
policy according to the inflation rate. The second reason is mainly empirical: whereas real wage increases are largely independent of the inflation rate, the interest rate and the inflation rate are highly collinear. Thus, unions are unable to negotiate real wage increases, but the central bank is able to target real interest rates.

6 The stability of the results for trade-weighted and unweighted data is also owing to the fact that the countries under observation all import more than $50 \%$ of their imports from the euro zone and less than $20 \%$ from the USA.

7 We also ran the regressions excluding the period following German unification (1990-4). Perhaps surprisingly, the inclusion/exclusion of these years does not alter the results.

8 We do not empirically determine the cut-off points (by Andrews or Chow tests) basically for two reasons. First, we test an institutional theory of monetary autonomy and this theory allows us to derive cut-off points theoretically. And, second, empirically derived cut-off points would not alter the results much, and might only reduce standard errors a little further.

9 This means that we model the present realization of the variance as a linear combination of the one-period lagged squared error terms and the one-period lagged forecast variance.

10 Values greater than 1 could lead to spurious estimates since the $\mathrm{ARCH}$ process would be explosive.

\section{References}

Alesina, Alberto and Robert J. Barro (2002) 'Currency Unions', Quarterly Journal of Economics 117(2): 409-36.

Bank for International Settlements (2004) 74th Annual Report. Basel: BIS.

Barro, Robert J. and David B. Gordon (1983) 'A Positive Theory of Monetary Policy in a Natural-Rate Model', Journal of Political Economy 91(3): 589-610.

Bayoumi, Tamin and Barry Eichengreen (1996) 'Operationalizing the Theory of Optimum Currency Areas', CEPR Working Papers.

Bernhard, William and David Leblang (1999) 'Democratic Institutions and Exchange-Rate Commitments', International Organization 53(1): 71-97.

Bernhard, William, J. Lawrence Broz and William Robert Clark (2002) 'The Political Economy of Monetary Institutions', International Organization 56: 693-723.

Broz, J. Lawrence and Jeffrey A. Frieden (2001) 'The Political Economy of International Monetary Relations', Annual Review of Political Science 4: 317-43.

Calvo, Guillermo A. and Carmen M. Reinhart (2002) 'Fear of Floating', Quarterly Journal of Economics 117(2): 379-408.

Eichengreen, Barry and David Leblang (2003) 'Exchange-Rates and Cohesion: Historical Perspectives and Political-Economy Considerations', Journal of Common Market Studies 41(5): 797-822.

Fleming, J. Marcus (1962) 'Domestic Financial Policies under Fixed and under Floating Exchange-Rates', IMF Staff Papers 9: 369-79.

Frankel, Jeffrey and Andrew Rose (1997) 'The Endogeneity of Optimum Currency Area Criteria', Swedish Economic Policy Review 4: 489-512. 
Frankel, Jeffrey, Sergio L. Schmuckler and Luis Serven (2002) ‘Global Transmission on Interest Rates: Monetary Independence and Currency Regime', NBER Working Paper No. 8828.

Franzese, Robert J. (2002) 'Electoral and Partisan Cycles in Economic Policies and Outcomes', Annual Review of Political Science 5: 369-421.

Galati, Gabriele and Kostas Tsatsaronis (2001) 'The Impact of the Euro on Europe's Financial Markets', BIS Working Paper No. 100.

Giavazzi, Francesco and Maro Pagano (1988) 'The Advantage of Tying One's Hand: EMS Discipline and Central Bank Credibility', European Economic Review 32: 1055-82.

Granger, Clive and Paul Newbold (1974) 'Spurious Regressions in Econometrics', Journal of Econometrics 2: 111-20.

Hausmann, Ricardo, Ugo Panizza and Ernesto Stein (2001) 'Why Do Countries Float the Way They Float?', Journal of Development Economics 66(2): 387-414.

Kaminsky, Graciela L. and Carmen M. Reinhart (1999) 'The Twin Crises. The Causes of Banking and Balance of Payments Problems', American Economic Review 89(3): 473-500.

Keefer, Philip and David Stasavage (2002) 'Checks and Balances, Private Information, and the Credibility of Monetary Commitments', International Organization 56: 751-74.

Kenen, Peter B. (1969) 'The International Position of the Dollar in a Changing World', International Organization 23(3): 705-18.

Lohmann, Susanne (1992) 'Optimal Commitment in Monetary Policy, Credibility versus Flexibility', American Economic Review 82: 273-86.

McKinnon, Ronald (1963) 'Optimal Currency Areas', American Economic Review 53: 717-25.

McKinnon, Ronald (2004) 'Optimum Currency Areas and Key Currencies: Mundell I versus Mundell II', Journal of Common Market Studies 42(4): 689-716.

Meese, Richard A. and Kenneth Rogoff (1983) 'Empirical Exchange Rate Models of the Seventies: Do They Fit out of Sample?', Journal of International Economics 14(1): 3-24.

Mundell, Robert A. (1961) 'A Theory of Optimum Currency Areas', American Economic Review 51: 657-65.

Mundell, Robert A. (1963) 'Capital Mobility and Stabilization Policy under Fixed and Flexible Exchange Rates', Canadian Journal of Economics and Political Science 29: 475-85.

Obstfeld, Maurice, Jay C. Shambaugh and Alan M. Taylor (2004) ‘Monetary Sovereignty, Exchange Rates and Capital Controls: The Trilemma in the Interwar Period', NBER Working Paper No. 10393.

Persson, Torsten and Guido Tabellini (1990) Macroeconomic Policy, Credibility and Politics. Chur: Harwood.

Plümper, Thomas and Vera E. Troeger (2005a) 'External Effects of Currency Unions', mimeo, University of Essex.

Plümper, Thomas and Vera E. Troeger (2005b) 'Efficient Estimation of TimeInvariant and Rarely Changing Variables in Finite Sample Panel Analyses with Unit Fixed Effects', mimeo, University of Essex.

Rogoff, Kenneth (1985) 'The Optimal Degree of Commitment to an Intermediate Monetary Target', Quarterly Journal of Economics 100(4): 110-24. 
Rose, Andrew (2000) 'One Money One Market, Estimating the Effect of Common Currencies on Trade', Economic Policy 30: 9-48.

Shambaugh, Jay C. (2004) 'The Effect of Fixed Exchange Rates on Monetary Policy', Quarterly Journal of Economics 119: 301-52.

Shambaugh, Jay C. (2005) 'A New Look at Pass-through', mimeo, Dartmouth College.

Wooldridge, Jeffrey M. (2003) Introductory Econometrics: A Modern Approach, 2nd edn. Cincinnati, OH: South Western College.

Wu, Yangru and Hua Zhang (1997) 'Do Interest Rates Follow Unit-Root Processes?

Evidence from Cross-Maturity Treasury Bill Yields', Review of Quantitative Finance and Accounting 8: 69-81.

\section{About the authors}

Thomas Plümper is Reader in the Department of Government, University of Essex, Wivenhoe Park, Colchester CO4 3SQ, UK.

Fax: +44 1206873234

E-mail: tpluem@essex.ac.uk

Vera E. Troeger is Lecturer in Political Science at the University of Exeter, Department of Politics, Amory Building, Rennes Drive, Exeter EX4 4QJ, UK, and a research fellow at the Max-Planck-Institute of Economics, Jena, Germany.

Fax: +44 1392263305

E-mail: v.e.troeger@exeter.ac.uk 